\title{
Conceptions of the value of higher education in a measured market
}

\author{
Michael Tomlinson ${ }^{1}$
}

Published online: 13 July 2017

(C) The Author(s) 2017. This article is an open access publication

\begin{abstract}
A critical analysis is developed of the dominant meanings of value in marketised higher education. In policy terms, this has become informed by the logics of the measured market whereby value has become synonymous with economic return and institutional accountability. The notion of value is one which permeates many discussions on the purpose of higher education and the perceived benefits it confers onto individuals and society as a whole. This, however, remains largely implicit and unearthing the specific meaning of value (and values) clearly presents challenges. This article critically examines a variety of concepts relevant to discussion of the value of higher education, including the relationship between value and quality, consumerism, goods and performativity. In each case, it unpacks their meanings and implications for the relationship between students and institutions, particularly at a time when this is seen to be increasingly transactional. It then outlines an alternative value framing to the utilitarian 'value for money' so prevalent in much market-driven policy.
\end{abstract}

Keywords Policy · Marketisation · Value $\cdot$ Quality · Employability · Consumerism · Goods · Performativity

\section{Introduction}

The notion of getting value for money, sometimes crudely expressed as getting 'one's money's worth', in relation to any consumer experience remains problematic given the many factors which mediate the judgement between value and perceived benefit (Sanchez-Fernandez and Iniesta-Bonillo 2007). When applied to higher education, the principle of 'value for money' opens up contentious issues, including the extent to which the value of higher education (HE) can be reducible to the economic returns it is purported to generate. This particular principle, however, has gained considerable traction in recent discussions on the future of

Michael Tomlinson

m.b.tomlinson@soton.ac.uk

1 Southampton Education School, University of Southampton, Southampton, Hampshire, UK 
higher education policy; particularly in national contexts where there have been an explicit policy drive to restructure higher education into a market-driven system (Brown and Carasso 2013; John and Fanghanel 2016). This has occurred at a time when considerable focus has been given to the wider economic contribution of universities and their reimaging as entrepreneurial knowledge service providers and suppliers of training (Barnett 2013).

The move towards a market-based HE system in England has gained significant momentum following the government-commissioned Browne Review into HE (DBIS 2011). This review resulted in a series of polices intended to place 'students at the heart of the system’. The most salient has been the raising of tuition fees from $£ 3375$ to $£ 9000$ in England, although this is one of a number of related policies, including the extension of student choice through the dissemination of key institutional performance data and uncapping places for highest achievers. More recently, the White Paper, Success as a knowledge economy: teaching excellence, social mobility and student choice (DBIS 2016) has proposed even greater institutional transparency in how effectively institutions provide value-added benefits for students. The key policy lever emerging from this is the Teaching Excellence Framework, intended to enhance teaching quality in English universities with potential implications for the variable fee level they can potentially charge students. This particular framework for evaluating teaching quality is predicated on there being a strong connection between institutional-wide teaching performance and subsequent student and graduate outcomes. Institutions' relative performance in this assessment will potentially determine their scope for setting higher fee charges, and therefore overall market standing.

Such patterns are evident in other national contexts. In the USA, the Postsecondary Institution Rating System (PIRS) was established during 2013-2015, and like the recent Teaching Excellence Framework in English HE, it was conceived to appraise institutions' relative value on the basis of performance on a range of core metrics designed to signal both their market attractiveness and potential for federal funding. These centered on throughput metrics linked to tuition, access and affordability and output metrics, including graduation rates, graduate earnings and take-up of advanced degrees (Hillman 2014). Whilst no longer operating as formal a cross-institutional rating system, the information generated continues to serve as a general consumer information tool intended to ramp up student choice.

In Australia, another market-driven context, the movement towards the further deregulation of student fees has encouraged institutions to compete more rigorously for students and resources (Sellar 2013). In this context, similar to England, considerable attention is given to formal measures that ostensibly indicate institutional effectiveness and competiveness, including the widespread measurement of student experience and engagement (ACER 2008). As Sellar (2013) argues, many equity policies, including widening participation and student choice largely co-exist alongside a neoliberal ethic of heightened student market rationality and self-interest. All these contexts operate effectively as measured markets. The systematic formulation and deployment of key performance measures serve as marker signals intended to influence the market choices and behaviours of student customers (Palfreyman and Tapper 2014; Hazelkorn 2015).

The limits of the market model for HE have been variously critiqued from a range of educational, ideological and structural angles (Lynch 2014; Collini 2012). One of the most immediate issues is that higher education does not function like a pure market system given that it is still funded and regulated principally by the state. There is therefore no direct relationship between supplier and purchaser based on flexible price mechanisms that is genuinely demand led. However, this has not necessarily prevented institutions from 
reimagining themselves as market units within a wider system of competition, consumer leveraging and reputational management (Marginson 2013). In attempting to adapt to the new market environment, many institutions have reframed their core mission and activities as tangible service providers and are engaging in reputational branding pursuits to attract a share of prospective students (Temple 2011).

This article develops a critical oversight of current market-driven policy goals through the conceptual lens of value. It first provides the context of marketisation and its relationship to concepts of value, examining the principles underpinning recent market-driven policy frameworks. It identifies several inter-linked market-driven motifs evident in recent policy discourse - quality, employability and economic competiveness - all of which are inter-related. The article then examines a number of significant conceptual themes in marketised higher education and their relationship to notions of value, namely consumerism, goods and performativity. It concludes by developing some alternative conceptions of value based on broader framing of how higher education may continue to benefit students beyond simply value for money. The article's main contribution is to demonstrate how market-driven HE systems and their related policies inculcate specific value orientations which explicitly enact students and institutions as economic agents whose value sets are exclusively utilitarian. These are also largely inimical to broader value orientations which have traditionally been associated with the higher education experience and which may serve students and graduates beyond simply maximising their market utility and agency.

\section{Marketisation and changing value of higher education}

There is no simple or unified approach to conceptualising value in relationship to higher education, or indeed to any other form of public or private life: concepts of value have a different meaning depending on the disciplinary lens being adopted. Unlike in economic theory where value is associated with the exchange mechanisms of price against productive expenditure, sociological and philosophical approaches have often been concerned with the ascription of value and the social and cultural processes which enable an object, experience or process to be become imbued with specific meanings (Smith 1992; Lamont 2012). Traditional approaches to the value of higher education have been linked to a liberal conception of universities as agents of personal and intellectual growth and (Newman 1854; Barnett 1990) make a strong connection between value and processes of self-formation and cognitive and social development: the enrichment of the so-called graduateness. The value of higher education is derived from its core institutional goal of transferring advanced knowledge onto those who can benefit, consequently empowering them.

Clearly relevant to the value concept in current higher education context are the dominant forms of value framing which have informed so much of the policy discourse and actual legislation around marketisation. It has become common to view the value of higher education in market-driven environments in relation to a process of commodification, or indeed reification, whereby what higher education produces is reducible to largely material and measureable market commodities. As such, higher education's value is derived from how much it can be traded or exchanged within what are essentially transactional relationships between individuals and institutions (i.e. between graduates, higher education and then employer organisations).

The value of higher education depicted in the English HE's 2016 White Paper is largely informed by the logics of economically driven human capital frameworks on the relationship 
between higher education and the wider economy (Becker 1993). Such a framework has clearly inspired much policy thinking on the need for structural reform, most specifically relating to educational expansion and fee increases. $\mathrm{HE}$ is often presented as generating wider economic value through not only the economically impactful research it produces but also the productive capacity of its graduates. This productive value translates into personal value in the economy, manifested in graduates' advantageous labour market opportunities and outcomes. In short, $\mathrm{HE}$ is conceived as a driver for economic growth and supply-side catalyst of a graduate pipeline which substantially enhances work organisations' marginal productivity (Mollar and Cuthbert 2015).

The commodification of value thesis is further related to the reframing of institutional actors' roles and response within institutions. The notion of value itself is reframed in principally utilitarian ways and higher education's key agents are encouraged to inculcate the value and belief systems of homo economicus (Skeggs 2014). The marketisation of HE is reported to actively encourage students to act as rational investors, informed choice-makers and indeed consumers, of their education. The credentials they acquire are positional goods within a largely positional market, and their relative value strongly determines the ways they are economically consumed in the future. For academics, the market appears to represent the appropriation of their labour towards instrumental goals, whether in terms of fulfilling wider performative imperatives that enhance their institution's global standing or exploiting personal research enterprises towards maximal socio-economic impact (Olssen 2016).

The tensions between the ends and means of education have been discussed in the classic works of Weber and Dewey who both examined the concept of value and values. In Weber's (1948) theorising, the relative value given to membership of an institution, or indeed ownership of a scarce resource, is the result of its status-enhancing function: individuals become bearers of value prized within a particular society or culture (having highly professional qualification, owning a relatively inaccessible good). This potentially reproduces the capacity for individuals to access other prized resources. Weber also made a distinction between instrumental and non-instrumental values. Instrumental value orientations (Zweckrationalitat) are those pertaining to the pursuit of discreet pre-determined ends, often material or economic. Education essentially becomes an instrument in itself towards the fulfilment of such ends. In this sense, an institution such as higher education becomes a distinguishable object of value, separate from the activities upon which it is constituted. The non-instrumental value orientation on the other hand (Wertrationalitat) refers to the end which is achievable and the means are themselves the processes which gives the end value and meaning. This is likely to entail some degree of internally purposive activities that more fully engages the processes by which an end is achieved, rather than being ostensibly geared towards that end.

As with Weber, Dewey's $(1939,1944)$ theorising also drew distinctions between means and ends or what are generally understood as a difference between intrinsic value and instrumental values. This has also been applied to educational contexts, particularly in exploring how the goals of an educational process might be conceived and feed into individuals' motivations. As an example, the development of instrumental values are shown to shape behaviours towards end-focused goals (e.g. grades, employability), often at the expense of educational ones (e.g. knowledge, deep learning). Similarly, if exchange value is predicated on the future economic utility of an individual's higher education, an individual's motivation may be largely driven by the fulfilment of end goals. This may have discernible impacts on their approach to HE learning, including engagement in learning and level of identification as consumers. Yet as Skeggs (2014) has discussed, Dewey's distinction between 'prising' something for its own 
sake and 'appraising' it in relation to externally imposed criteria are not always far removed in market contexts.

Value is clearly a challenging concept, but it has been given a definite framing in marketdriven policy frameworks. The rest of this paper looks at various conceptual lenses relevant to how higher education can be explored. It starts off by exploring the current HE policy framing, particularly through the dominant perennial policy themes of quality and employability which, in the current proposals, are closely related.

\section{Quality, employability and economic competiveness: dominant mantras in market-based HE policy}

In market-driven systems, a number of key principles underpin both the actual policy levers and the textual make-up of related policy discourse, all of which have salience to the notion of value. In recent UK and US reform notions of quality, employability and economic competitiveness are presented as being inter-linked. Quality is depicted as a driving goal for higher education: students who receive high-quality education not only get an immediate and future return on their investment but also acquire a level of education that equips them well for future economic life. The 2016 English White Paper argues that the reforms:

....will introduce more competition into the system. This will be underpinned by proportionate oversight by a single regulator to ensure choice, quality, fair access and value for money, recognising the many economic and social benefits that higher education brings to the country. Properly regulated, a competitive higher education market will create stronger, higher-quality providers that will further enhance the global reputation of the sector and will serve students, employers and taxpayers better (p. 23).

The time-honoured references to employers, skills and economic benefits underscore much of the arguments in this paper: higher education is a supplier of economically valuable knowledge and skills and efforts needs to be channelled towards maximising their effective delivery. The two main stakeholders of higher education, student and employers, accordingly demand a set of experiences and outcomes which is commensurate to both the public and private investment higher education receives. One of the key features of the recent English White Paper is the equation of value to economically based outcomes, including students' employability and the relative market value of degrees - hence the foregrounding of value for money. Value for money is referenced against what students formally acquire from higher education and in turn are able to exchange for potential economic return. The task is making sure that both the immediate and future value of their experience is enhanced and higher education's formal operations are geared towards this goal.

The US HE system has operated along market lines for much longer and notions of affordability, accountability and quality are inextricably connected to the perceived value of institutional offerings (Kelchen 2014). The underlying rationale for explicitly linking quality and perceived value appears to be the quest to find transparent and measurable ways of regulating institutional activities towards service improvement and efficiency. However, as Blanco Ramirez and Berger (2014) discuss, the reduction of quality-accountability approaches to technical criteria in US HE has largely had the effect of marginalising more finegrained, process-level markers of quality, including innovative pedagogic practices. A further effect has been the restriction of institutional autonomy and more bottom-up initiatives, 
particularly where these do not accord with more populist and pragmatic concerns with formal outcome measures.

Quality in this and other market contexts is related to the explicit framing of the 'student-asconsumer' who demands and expects a transparent level of service fulfilment. An obvious and immediate link is drawn between incremental increases in student tuition fees and the need for higher education to be increasingly responsive to student demands. Value in higher education has long been associated with quality and the extent to which students' experiences match legitimate expectations about what their institutions provide (Harvey and Knight 1996). However, there is significant variance in the meaning of quality; although what clearly unites different conceptions of quality is the idea of some degree of professional and institutional accountability and responsiveness in meeting stakeholder demands.

As Harvey and Knight have outlined, the meaning of quality can range from prescriptive and normative criteria such as value for money to ones which facilitate genuine transformation in students' lives. The 2016 White Paper is framed comprehensively around the former, linked to risk-based auditing whereby service providers are adequately equipped to fulfil external agents' or consumers' needs. The 'value as transformation' criteria (potentially carrying higher institutional risks) based on empowering learners and 'giving students more control over the learning' is seldom explicitly discussed.

A strong causal connection is made between teaching quality and student outcomes: teaching quality adds immediate value to outcomes, defined in terms of the future exchange value of their degrees. An underlying theme is the need for provider responsiveness in the face of heightened expectations on the value and returnability of studying in higher education. The future 'employability' of graduates is couched in terms of the 'investment' students make towards higher education and attendant expectations of tangible returns in the labour market. Recent UK policy makes an explicit connection between high-quality teaching and future graduate employability, although this specific connection is not expounded beyond the deduction that one directly influences the other. One of the core goals of higher education is the future employability of graduates: the key rationale for participating in higher education. The more that formal teaching provision can be geared towards this goal, the more students will benefit on leaving university. However, the relationship between supply-side provision and employability both in generic terms and in relation to specific modes of curricula which are purported to enrich graduates' 'skills' is far from straight-forward (Mason et al. 2009; Keep 2012; Mollar and Cuthbert 2015). As Harvey (2001) has discussed, the quality-employability relationship implies a somewhat simple ('magic-bullet') causality. This position, however, is abundant in the UK White Paper which adopts a somewhat crude and decontexualised approach to employability. However, as much of the conceptual literature in this field illustrates, this is a complex and multi-dimensional issue shaped by demand-level factors in the labour market as much as supply-side provisions (Forrier and Sels 2003; McQuaid and Lindsay 2005).

The paper now examines the idea of the value of higher education through a number of significant and salient conceptual lenses, all of which map onto current policy ideas and the role of students in the system.

\section{Value and consumption}

The enactment of students as consumers is very real in market-driven HE systems. Whilst much of the discussion operates at a symbolic and rhetorical level linked to the rising 
individual costs of participating in HE, a regulatory framework has emerged which seeks to protect students' 'consumer rights' (CMA 2015). This includes the potential prowess current students have in regulating the services they experience and, where applicable, questioning their provision if it does not align with identified expectations on arriving. This has been a popular policy framing and much of the media discussion has either endorsed this position or presented something of a moral panic on its prevalence and impacts. There is a strong sense that fee-paying students inevitably view their higher education as a commodity to be purchased and consumed in a similar way to other goods and services. This fundamentally shapes their relationship to their institution and their attitudes and behaviours when in higher education. Students are now understood to bring consumerist entitlements into a process that has traditionally demanded rigorous academic expectations and the expenditure of intellectual effort. This further entails a provider strain on the part of universities in meeting sometimes unsolicited consumer demands from which they have been traditionally insulated.

The problems linked to conceiving higher education as a consumer service or product have been extensively discussed and challenged (see Molesworth et al. 2010; Naidoo et al. 2011). These range from critical pedagogic approaches to challenges around the specific meanings of the student-consumer and how effectively it may be applied to higher education. The so-called consumerist turn in higher education, whether active or notional, has significant implications for the perceived value of HE. Thus, if there is a movement towards growing consumerism amongst the student population, what does this signal about the value ascribed to their experiences and the outcome it generates?

In consumer economics and marketing, the principles of 'value-based' pricing are used to frame the stipulated value of a product even if it does not correspond to its actual value. This follows the logic that customers are prepared to purchase a product at an inflated level if its ascribed value exceeds its real-term costs. Prices of course can be heavily manipulated so that perceived value exceeds its genuine value. The novelty, relative uniqueness and demand of a product are such factors in framing its conferred value. Conversely, the perceived depreciation of product, its declining status and lack of demand can lower its price. This cost-value approach is also sometimes used to frame the relationship between cost and quality, although there may be some degree of reversed causality in this relationship: price can precede quality, rather than being determined by its actual value. In a market environment, educational institutions often like to be seen to compete in quality rather than just price, although by default price is often seen as a proxy marker of quality (Brown and Carasso 2013).

There are several emergent discussions from empirical and critical research on consumerism in $\mathrm{HE}$ and its relationship to value. One concerns the problems, and potential limitations, of introducing a consumer market into a system which has traditionally been linked to the development of outcomes which cannot be defined exclusively in terms of simple service value. A relevant issue here is that higher education remains a future-orientated (postexperience) good: it is one which students more likely invest in rather than immediately consume. Its value therefore is assessed in terms of longer-term impact rather than immediate fulfilment. At its extreme, this may lead students to evaluate how an immediate higher education experience may be referenced against a future outcome; in many instances, the question of 'what use will this be for my future' may prevail. However, even though universities may endeavour to extensively inform new 'purchasers' about the service experience they can expect, students will not necessarily have full and accurate knowledge as to what they will be consuming at the point of entry. 
Students may well extrapolate a specific financial value to a formal educational experience because they can now easily calculate the cost specifics against their overall net personal contribution. Yet, it is less clear in such valuations whether this is actually based on a calculation of its economic value. It has become commonplace to infer that the equation of an educational experience to any value is strongly premised on its monetary worth rather than its actual experiential, or indeed temporal, worth - that is, value for time. It is more than possible that when an educational experience is appraised in relation to a value, this is based on its existential value (and related costs) rather than simply its economic value. The potentially transactional relationship between student and institutions as a result of increased fees can potentially reinforce whether an educational experience is worth the very physical act of participating for a determinate period of time. Having the freedom to choose would at one level signal consumer discretion in the same way that a real consumer can decline participation on these grounds. However, a paradoxical feature of most UK institutional protocols is the mandate that students compulsorily attend sessions under the remit of 'student engagement' and making proactive class contributions (Macfarlane 2013).

Another theme in the consumer literature is the actual reduction of value that consumerism brings to the end outcome of higher education, a theme which has been illustrated in numerous empirical studies on students' experience within higher education. One reason that fee-paying students may actually resist the label of 'student-consumer' is the concern that 'buying a degree' carries a negative signal to significant others who may also be involved in the valuation of higher education (Tomlinson 2017; Williams 2012). In reflecting upon their ascribed status as 'consumers', students are often more than aware of being 'positioned' into specific categories by significant others - media, institutions and lecturers. An underlying concern is the potential reduction of value to degree qualifications when reduced to a form of consumerism, indicating diminished cognitive effort and a lack of agency in the attainment of the outcomes. The concern is that consumerism denotes passive receipt of university goods and such some distancing from that approach.

The relationship between consumer-based learning orientations, academic motivation and academic outcomes has not been extensively researched, although there is some strong emerging evidence that students whose learner identities and related motivational sets have a consumer affiliation are likely to achieve less academically (Bunce et al. 2016). This relates to motivational literatures which posit that the less value individuals attach to an activity for its own personal benefits, i.e. its intrinsic reward, the less will be their engagement and consequent achievement. Such research suggests that valuing a degree on its pure economic value entails problems for academic quality and engagement. One of the concerns around consumerism amongst academics is the anticipated need to appeal to the lowest common denominator and compromise the pedagogic values they hold, including the principles of subject rigour and depth of understanding (Lomas 2007).

\section{Value and goods}

Another area of value relevant to market-driven HE systems relates to the multiple and often contestable nature of 'goods' and the role of universities in producing and distributing them. The conventional social definition of goods as things which are produced and then distributed at a social or individual level is a useful starting place in such discussion for it conveys the notion that goods essentially generate value to those who can benefit from their existence, 
whether that is society at large or private individual level. Four potential conceptualisations of goods are identified here, each carrying implication for the value of higher education in its marketised context. These are seen in terms of public, private, positional and complementary goods.

The first of these, public good value, refers to goods which are widely distributed within the public domain, having been produced within a public institution which is sustained through public means (Samuelson 1954). The clearest example of this is university knowledge which is able to permeate societies beyond the walled garden of the academy and has potential societal value. The two public dimension of public good-being non-rivalrous and non-excludable-imply that the wider benefits and value of higher education in the form of knowledge are widely shared beyond the immediate producers and consumers of knowledge. In a broad sense, public goods also potentially extends beyond the civic and public sphere and may also encompass economic life. An example is the secondary effects of skilled graduates passing on knowledge within a workplace context, potentially enhancing the productive capacity amongst those who have not personally benefited from higher education. Knowledge and skills which are largely privately developed, can impact on wider social development if used effectively by others who have not benefited.

However, a strong feature of current policy framing on the value of higher education, particularly when linked to economic benefits, is around its private good value - that is, something which is privately funded, consumed and utilised for personal future economic return. Value here clearly works at an individual level with the attendant expectation that the holder of the private good does all they can to maximise the private gains associated with its acquisition so that it can potentially advantage them against others who have similarly acquired such goods. Private goods to this extent inculcate private values and orientations that embody market individualism and a concern that whatever private goods one accrues are exclusive and, to a large extent, in competitive demand. This has immediate implications for students' relations to universities and how they value (and valuate) their experience: higher education is a largely individualistic pursuit that generates personal gains. The key issue here, however, is that for private returns to be valued, they must have some purchase on the future lives of the holder in the sense that the connection between the good and its future external value is tangible. Given that private goods are effectively post-experience goods, their value is derived from the material private benefits that extend beyond immediate experience.

Private goods also function as positional goods as they confer private advantages which are exclusive to the individual holder and therefore potentially excludable to others. However, the value of positional goods in this sense is complicated by the massification of qualifications and the fact that many individuals are seeking to transfer similar goods in exchange for similar types of return. The idea of positional goods relates to wider structural current trends in higher education, namely the enduring nature of inter-institutional competition, nationally and internationally. This impacts on the ways in which institutions are perceived in relation to each other and are presented publically. The historical value attached to the private and positional goods that higher education distributes clearly continues to drive its demand amongst those who are able to access it, reflecting the continued participation amongst the middle and aspiring middle classes.

One of the main consequences of mass higher education, as highlighted by signalling theorists, is that as the demand for, and consequent acquisition of, positional goods rises, the value of these goods declines (Dore 1976). Mass higher education has been the 
growth in credentialism and the related increase in grade inflation. Consequently, the value of individuals' human capital (one of the main markers of a private good) has declined over time as reflected in large-scale data on graduate returns (Future Track 2013). Therefore, when private goods are widely distributed and do not necessarily facilitate access to scare economic rewards (exclusive and well-paid employment), there have to be further markers of their value.

Whilst many higher education systems may not resemble a pure market, they still resemble to a large extent a positional market (Brown and Carasso 2013; Marginson 2011) based on enduring levels of internal stratification and differentiation. In positional markets, status and vertical systems of internal stratification are very much in force. This is largely based on the historical reputational value conferred onto different institutions, invariably linked to their research stature. It is widely acknowledged that an institution's status is an antecedent factor in an institution's market standing and conferred quality rather than an objective measure of what it provides in terms of institutional quality. This in turn potentially ramps up ascribed value given to different institutions and consequent demand amongst prospective students and employers. Competition rhetoric often depicts market neutrality whereby quality can be judged on the basis of what institutions provide and produce rather than pre-existing differentials in terms of resources and academic composition of student-factors which may play a considerable role in determining their formally assessed value added.

The relative value given to specific types of institutions, based on value-added institutional capital has significant implications for the resource differentials, potentially leading to inequitable competition between institutions. As Marginson (2011) argues, one of the main challenges to the public good value of universities is not so much the movement towards stronger market freedom in the true sense but the intensification of extant status markets. One approach in adapting to inevitable status differentiation has been for institutions to present alternative versions of value beyond simply their reputational status and look to exploit whatever market signals they can, including specialist services, modes of provision and purported student outcomes. Consequently, many lower-ranked institutions may well look to exploit formal performance-based market information in projecting positive signals about the specific offerings and benefits associated with their institutions.

Another way of conceptualising the relationship between 'goods' in relation to the exchange between individual and institution, and the potential value this generates, is to frame this in terms of complementary effort in their production. The notion of complementary goods is one which captures the mutual production, indeed co-production, of goods within the institutions and which entails some degree of co-ordinated endeavour, communication and shared understanding between providers and recipients of a good. Accordingly, if a good is based on some mutual effort between provider and user, and the latter does not maintain their part in this process, then the value of their experiences and related outcomes is likely to be depleted. As such, limited value can be extracted from a service if there is little reciprocal interplay between provider and user. In a context such as higher education, this exchange relationship, particularly when it generates sometimes intangible gains, is one way of potentially buffering institutions from unreasonable consumer strain in a form of a one-way set of demands.

The simplest analogy here is gym membership: a gym member may easily criticize the facilities and overall service quality on legitimate grounds and therefore be compelled to use the services of another provider. If, on the other hand, the gym customer asserts that their overall fitness has not been enhanced because of limited service quality, this takes out of the equation their personal role in maximising their chances. The gym facilities might of course be one way of attributing minimal health gain, but this is a tangential factor if minimal effort is 
expended when using the services. As an antidote to consumerist, private good ethos, the notion of the complementary good brings into play the level of co-production or reciprocal exchange between provider and user. The process of co-production gives a greater value to the experience as it entails greater levels of personal input and meaning than simply the passive use of a service.

\section{Value and performativity}

A prominent feature of current higher education which carries implications for value is the move towards system-wide performativity which has been shown to be increasingly at work amongst academics, students and institutions at large (Ball 2012; Macfarlane 2013). In the academic literature, the concept of performativity is strongly associated with the spread of measurable performance in educational institutions through metrical modes of compliance and other quantifiable proxies of educational output. Performativity refers to a 'governance by numbers' ethic (Ball 2015), which effectively enables institutions, and individuals within them, to be evaluated and scrutinised in terms of their measured output. This is typically referenced against the competitive ordering which market-driven policy systems have engendered. It also has the effect of both weighting value onto specific types of institutional activities and outputs, as well as potentially tuning individuals' values towards the accomplishment of quantifiable markers of their achievements.

The preponderance of measurement and measurability within higher education is clearly prevalent in the managed market environment and is used to incentivise behaviours which serve the end goals of favourable market positioning. The attainment of desired outcomese.g. research ranking, student satisfaction, teaching quality, graduate employment outcomesbecomes a driving incentive and can marginalise other areas of institutional life which cannot be quantified into set units of production. Performative value can therefore be seen in terms of the value placed on quantifiable outcomes and the activities which has potentially affected their successful accomplishment. A paradox here is that whilst the behaviours that performative regimes engender supposedly serve institutional ends, they ultimately inculcate highly individualised behaviours that resemble competitive gaming within and between institutions (Olssen 2016).

Much has been written on the ways in which performativity has shaped institutional behaviours amongst academics and managers in HE, including responses to research output and league table fixation (Locke 2014; Lynch 2014). The link between performativity and student education has more recently been observed and when applied to student education is based principally on the fulfilment of measurable outcomes of student experience, ranging from student satisfaction, student engagement and increased measures of 'learning gain'. In measured markers, teaching quality is depicted as a vehicle for institutional effectiveness, providing a catalyst for students' future employability and returns. Rather than just serving as a basic market signal, this is often attributed to a set of institutional factors, including the quality of provision, student support, curricula relevance and employer links - all of which better affect the performative goal of generating enhanced employment rates. Yet, as has been highlighted earlier, there is no firmly established link between institutional factors and future outcomes.

Performativity can also result in a process of so-called gaming on the part of students (Macfarlane 2016), including approaches to assessment and jumping through whatever hoops 
they can to attain desired outcomes. The stronger value that a student might place on acquisitive learning (i.e. learning which is extrinsically orientated towards acquiring desired outcomes) rather than inquisitive learning (i.e. learning for its own intrinsic interest and personal fulfilment) may be premised on the lack of measurable or future return value given to the latter. There are clear overlaps between academics' performativity and that of students, including the enduring pre-occupation with performance outcomes which may have minimal relationship to higher learning or processes of intellectual formation. At the crudest level, this is manifested in the 'cult of the grade' which appears to have intensified over the past several decades as a response to mass HE. The grade is effectively a marker of performative value, signalling the potential value of one's achievement relative to the achievement of others.

Another salient issue is the continued devaluation of lower-achieving grades amongst students to the point of cancelling any value to their higher education experience if a specific grade threshold has not been met. In the UK and USA, the increasing move towards 'gradepoint averages' may not necessarily resolve the problem of 'grade inflation' and the continued devaluing of higher-level qualifications. Apart from potentially making lower degree outcomes even less valuable in the market, it could intensify students' perceived need to achieve a specific grade threshold therefore encouraging further gaming amongst students and institutions. The proportion of high-grade students at an institution is currently a key market signal and indicator of teaching effectiveness, but the evidence indicates that employers do not necessarily see grade outcomes as a useful marker of graduates' potential (Cai 2013).

Performativity can operate in the teaching and learning environment amongst academics and is not just confined to research output and enterprises. A performative teacher might be construed as one who does what they can to maximise the best possible outcomes, including retention and student performance. This raises critical issues in the area of 'student engagement', which is now taken to be the panacea for enhancing the formal student learning experience (Baron and Corbin 2012). Much of the current discourse and related policy on student engagement suggests that this agenda is an uncontested good given the purported student-centred learning approaches practices it engenders. However, as has been pointed out in critical literature (Zepke 2014), if this is based on largely behavioural measures it risks having a performative function with questionable learning benefits. Relatedly, formal measures to assess this, including student engagement surveys, can have a largely behavioural and performative underpinning, particularly when associated with criteria around student satisfaction.

\section{Value beyond value for money?}

As higher education systems evolve and their functions proliferate beyond walled institutional pursuits, questions about their value take on a more significant meaning. This extends to subquestions concerning how value is measured and appraised, to what end and in what form. Moreover, the relationship between purely intrinsic means-focused value foci and instrumental end-focussed ones becomes increasingly blurred as the functional remit of HEIs expands (McCowan 2016). In a shifting institutional context, characterised increasingly by commodification, value can also take on a discernibly ambivalent character with multifarious ends (Weiler 2005). Drawing on the example of German higher education, Weiler illustrates how many high performing institutions are often caught between competing and contemporaneous value systems: between the residual logics of traditional scholastic endeavour and disciplinary 
affiliation and the more enterprising, managerially facing practices of the new academic capitalist order.

There remain a number of alternative value framings to the ones prevalent in current marketized policy discourse. The first concerns the reconnection with the intrinsic value of higher learning, which, if extended to more recent concerns with formal student experience, appeals to higher education's emancipatory scope for effecting genuine change amongst students. Drawing upon critical commentary over concern over the rising populist disparagement of 'non-returnable' liberal degree programmes in the USA, Jones (2013) discusses how post-experience utility discourses of value largely underplay post-experience effects which are not directly convertible into economic positional advantage. Traditional liberal conceptions of value have often made an implicit reference to the notion of graduateness, understood mainly as the developmental manifestations of what a graduate has acquired - cognitively, socially and culturally - from HE. Newman's writings offered no simple bifurcation between the intrinsic and instrumental value of higher education knowledge: HE embodies powerful knowledge which, whilst not necessarily having a direct economic trade-off, could still empower recipients towards living more meaningful future lives.

Liberally centred value approaches posit that intrinsic value represents more than merely a soft value which confers mainly tacit benefits associated with pursuing higher education. More recent discussions of the link between higher education and self-formation show that both formal and informal experiences of higher education can significantly enhance student agency and build a variety of capitals, including personal and identity capital (Marginson 2014). Human capital, currently the dominant value marker, is only one component of higher education's personal value alongside its potential for enhancing students' self-knowledge and relationship to self and others. Much of the informative research on student engagement has shown the potential impact of higher education, including the enhancement of students' socapacity to self-regulate as learners and make independent choices (Coates and McCormick 2014). A university degree only becomes meaningful if it embodies experiences and forms of learning that are empowering to individuals and enhances personal autonomy (Schneider 2008).

A related developmental approach which has helped re-orient the value of educational activities beyond the economic is the capability approach of Sen $(1985,1999)$. This has offered important insights to discussions of educational value, particularly as alternatives to dominant economic growth models. The capabilities perspective ultimately provides a broader value framing, encompassing students' personal empowerment through enhanced agency and having choices to pursue educational and vocational pathways that they have reason to value. In dominant utilitarian perspectives, the relationship between agency and value centres on an individual's capacity to act in rational ways that help self-optimise their personal economic return and market utility. Capability approaches however conceive agency in terms of an extension of individuals' freedoms to make more deliberated choices based on selfreflexive judgements about their feasible scope to pursue pathways and goals they have reason to value.

One of the central tenets in Sen's conceptualising is the potential for educational experiences to provide students with opportunities to pursue a worthwhile future pathway (employment-related or otherwise). Yet, this is only meaningful if their acquired capabilities are given opportunities to be converted into genuinely attainable outcomes. The life of a graduate extends well beyond the immediate economic imperative of finding initial employment and may also include other life projects and goals. One of the key principles of the capabilities 
perspective is that an individual's value, including the values they hold, is in no sense exclusively confined to their economic capacity. Their abilities or potential to generate personal economic return or add collective economic is only one value domain. Instead, individuals' capabilities are linked to more holistic aspects of their development and selfhood, including their capacity for reason, judgement and enhanced autonomy. Value is only meaningful if it represents the capacity for individuals to act with relative autonomy and fulfil whatever capability sets they have acquired. If the criteria of value, for instance, concerns intrinsic goals around doing a creative and socially orientated job, then this becomes a guiding principle for an individual's goals and actions.

When relating the value of higher education to graduates' broader capability sets, employability and future returns are not necessarily marginalised from this approach given their centrality to current students' motivation. However, the means through which these are acquired become important, including what is acquired in the process that has enhanced their capacity for action and potential well-being. The object of value therefore shifts from valuing something as an end itself (resonant with one feature of Weber and Dewey) towards the extended freedoms individuals have to live creative and meaningful lives. This approach helps reclaim the scope for students and graduates to make purposive valuations about the extent to which higher education has enabled them to pursue options they have reason to value. In moving the concept of value beyond transactional utilitarianism, wider questions about what higher education can do for students and what their own role is in the process therefore become more prominent.

\section{Discussions and conclusions}

Recent policy developments, particularly in liberal political economies such as the UK, USA and Australia, necessitate greater discussion of the value of university for students and graduates, including some of the contestable ways in which it is conceived at a policy level. There are clearly a number of corollaries to the current market-driven environment, all of which have wider implications for the meaning of the value of higher education. In unpacking these meanings in a marketised context, and particularly in relation to students' educational experience, this article has shown how that this is now strongly informed by the following:

- An explicitly utilitarian policy framing of the economic value of higher education, collectively and individually;

- The promotion of consumerist behaviours amongst students who are encouraged to view the value of their higher education as a private, positional good which enhances their own relative personal value in the labour market;

- The preponderance of discourses around competition within the sector, often presented as a lever for enhanced quality and graduate outcomes;

- A pre-occupation with performative outcomes and exercises intend to capture the added value, or indeed performance-enhancing quality, of institutions which in turn potentially strengthens their formal standing.

This article has located these drivers, and their relationship to the concept of value, in a wider context. This context not only concerns the operation of the managed market in neoliberal political economies but also wider contextual factors around massification and the changing 
economic context in which they operate, both fiscally and structurally. The value of HE has become almost exclusively framed in terms of what it constitutes and generates economically. One particular feature of many of the market-driven reforms is that they often present a deficit narrative: HE providers do not sufficiently reach the requisite standards now demanded in a market place where the considerable power has been leveraged onto paying customers. The subtext is that institutions need to exercise more robust forms of market accountability that align providers' throughputs and outputs to students' future economic needs.

Another feature of recent market-driven policy, as evident in its largely metric- and outcomedriven approach, is the principle of commensuration (Espeland and Stevens 1998). Commensuration in this context refers to the reduction of complex phenomena, which are largely socially and contextually embedded, to metrical and outcome-based criteria. This includes not only the problem of employability, but also the actual process of teaching and learning which is purported to enhance graduates' future outcomes. It further entails the adoption of largely homogenised units of assessments (i.e. pan-national and inter-institutional teaching quality markets) ahead of more fine-grained consideration of how this is played out in diverse institutional settings with heterogeneous types of learners and programmes.

The extent to which current market-driven policies can overcome these challenges is open to some debate. When HE becomes more market driven and students are encouraged to perceive their role as consumers and institutions are reframed as 'delivery agencies', the perceived value of institutions is largely referenced against their market standing and what future returns they generate (Brown and Carasso 2013). This is where lies the 'value-for-money' trap to which most market-led HE systems appears to be succumbing, which also potentially serves to reinforce the vertical segmentation in the system. The introduction of incentives in the form of competition for more students via higher fee tariffs assumes that a strong element of market neutrality exists. Institutions are seen to operate on a largely equitable basis and their positions determined by the institutional quality they internally generate. This significantly downplays the rules and logics of positional markets. Whilst higher-ranked institutions are able to couch their quality in terms of historical antecedents of value linked to an academically elite body student and academics, they have not lost sight of the changing game rules. Lower-ranked institutions will seek to raise perceived value through formal metrics and other related marketing devices; although, as much of the analysis on student choice has shown, perceived quality and value are pre-determined to a large degree by status precedents.

Promoting quality of teaching and finding ways of enhancing student experience is agreed by most to be a laudable aim, as is the endeavour to create some level of parity between teaching and research. It is less apparent in current English policy proposals how this divide will be resolved. Moreover, recent HE policy downplays the complex relationship between these two areas. At a within-institutional level, the relative value given to these different areas has sometimes given rise to intellectual labour divisions in the attempt to balance competing institutional priorities. 'Research-led' teaching is seen as a means of addressing this tension, but measures to formally institutionalise this have not always evolved beyond rhetorical aspiration. At an inter-institutional level, the research-teaching division is even more pronounced and has already given rise to significant resource and reputational divisions in amongst institutions. The idea that teaching-led institutions will surpass research-driven ones because of the greater attention and resources given to teaching activities somewhat overlooks the complex mixture of institutional, academic and student profiles in different institutions and the ways in which these frame judgements of quality.

The language of the student-as-consumer has gained considerable potency in recent marketisation policy, further evident in moves towards formally protecting students' 
'consumer rights' through the promotion of service-level expectations. The consequences of this position, however, require further critical consideration - not only amongst policy makers but also within institutions. Much of the critical analysis and emerging evidence indicates the potentially deleterious impacts of consumerist approaches on quality of learning and the overall value of students' educational experience and related outcomes.

Open Access This article is distributed under the terms of the Creative Commons Attribution 4.0 International License (http://creativecommons.org/licenses/by/4.0/), which permits unrestricted use, distribution, and reproduction in any medium, provided you give appropriate credit to the original author(s) and the source, provide a link to the Creative Commons license, and indicate if changes were made.

\section{References}

Australian Council for Educational Research (ACER). (2008). Attracting, engaging and retaining: New conversations about learning. Australasian student engagement report. Camberwell: ACER.

Ball, S. (2012). Performativity, commodification and commitment: An I-spy guide to the neoliberal university. British Journal of Educational Studies, 60(1), 17-28.

Ball, S. (2015). Education, governance and the tyranny of numbers. Journal of Education Policy, 30(3), $299-301$.

Barnett, R. (1990). The idea of higher education. Buckingham: Open University Press.

Barnett, R. (2013). Imagining the university. London: Routledge.

Baron, P., \& Corbin, L. (2012). Student engagement: Rhetoric and reality. Higher Education Research and Development, 31(6), 759-772.

Becker, G. (1993). Human capital: Theoretical and empirical analysis with special reference to education (3rd ed.). Chicago: University of Chicago Press.

Blanco Ramirez, G., \& Berger, J. (2014). Rankings, accreditation and the international quest for quality: Organizing an approach to value in higher education. Quality Assurance in Higher Education, 22(1), 88-104.

Brown, R., \& Carasso, H. (2013). Everything for sale: The marketization of UK higher education. London: Routledge.

Bunce, L. Baird, A. \& Jones, S. (2016). The student-as-consumer approach in higher education and its effect on academic performance. Studies in Higher Education (forthcoming).

Cai, Y. (2013). Graduate employability: A conceptual framework for understanding employers' perceptions. Higher Education, 65(4), 457-469.

Coates, H., \& McCormick, A. C. (Eds.). (2014). Engaging university students: International insights from system-wide studies. Dordrecht: Springer.

Collini, S. (2012). What are universities for? London: Penguin.

Competition and Markets Authority. (2015). Higher education undergraduate students: Know your rights. London: CMA.

Department for Business, Innovation and Skills. (2011). Higher education: Students are the heart of the system. London: HMSO.

Department for Business Innovation and Skills. (2016). Success as a knowledge economy: Teaching excellence, social mobility and student choice. London: HMSO.

Dewey, J. (1939). Theory of valuation. Chicago: Chicago University Press.

Dewey, J. (1944). Some questions about value. Journal of Philosophy, 41(17), 449-456.

Dore, R. (1976). Diploma disease: Education, qualification and development. Berkeley: University of California Press.

Espeland, W. N., \& Stevens, M. L. (1998). Commensuration as a social process. Annual Review of Sociology, 24(1), 313-343.

Forrier, A., \& Sels, L. (2003). The concept of employability: A complex mosaic. International Journal of Human Resource Development and Management, 3(2), 102-124.

Future Track. (2013). Transitions into employment, further study and other outcome: The future track stage report 4. Warwick: Warwick Institute for Employment Research.

Harvey, L. (2001). Defining and measuring employability. Quality in Higher Education, 7(2), 97-109.

Harvey, L., \& Knight, P. (1996). Transforming higher education. Bristol: Open University Press.

Hazelkorn, E. (2015). Rankings and the reshaping of higher education. Basingstoke: Palgrave Macmillan.

Hillman, N (2014) College ratings: What lessons can we learn? http://www.learningoutcomesassessment. org/documents/HillmanViewpoint.pdf.

John, P., \& Fanghanel, J. (Eds.). (2016). Dimensions of marketisation in higher education. Abingdon: Routledge. 
Jones, G. (2013). Rates of exchange: Neoliberalism and the value of higher education. International Studies in the Sociology of Education, 23(3), 273-280.

Keep, E. (2012). Educaton and industry: Taking two steps back and reflecting. Journal of Education and Work, 25(4), 357-379.

Kelchen, R. (2014). Federal College Ratings: A primer and potential implications. Journal of College Admission, $225,12-15$.

Lamont, M. (2012). Towards a comparative sociology of valuation and evaluation. Annual Review of Sociology, $38,201-221$.

Locke, W. (2014). The intensification of rankings in an increasingly marketised higher education environment. European Journal of Education, 49(1), 77-90.

Lomas, L. (2007). Are students' consumers? Perceptions of academic staff. Quality in Higher, 13(1), 31-44.

Lynch, M. (2014). New managerialism, neoliberalism and ranking. Ethics in Science and Environmental Politics, 13(2), 141-153.

Macfarlane, B. (2013). The surveillance of learning: A critical analysis of university attendance. Higher Education Quarterly, 67(4), 386-373.

Macfarlane, B. (2016). The performative turn in the assessment of student learning. Teaching in Higher Education. doi:10.1080/13562517.2016.1183623.

Marginson, S. (2011). Higher education and the public good. Higher Education Quarterly, 65(4), 411-433.

Marginson, S. (2013). The impossibility of capitalist markets in higher education. Journal of Education Policy, 28(3), 353-370.

Marginson, S. (2014). Student self-formation in international education. Journal of Studies in International Education, 18(1), 6-22.

Mason, G., Williams, G., \& Cramner, S. (2009). Employability skills initiatives in higher education: What effects do they have on graduate labour market outcomes? Education Economics, 17(1), 1-30.

McCowan, T. (2016). Universities and the post-2015 development agenda: An analytical framework. Higher Education, 72, 505-523.

McQuaid, R. W., \& Lindsay, C. (2005). The concept of employability. Urban Studies, 42(2), 197-219.

Molesworth, M., Scullion, R., \& Nixon, E. (Eds.). (2010). The marketisation of higher education and the student a consumer. London: Routledge.

Mollar, T., \& Cuthbert, D. (2015). The issue of research graduate employability in Australia: An analysis of the policy framing (1999-2003). The Australian Educational Researcher, 42(2), 237-256.

Naidoo, R., Shankar, A., \& Veer, E. (2011). The consumerist turn in higher education: Policy aspirations and outcomes. Journal of Marketing Management, 27(11-12), 1142-1162.

Newman, J. H. (1854). The idea of a university. New York: Image Books.

Olssen, M. (2016). Neoliberal competition in higher education today: Research, accountability and impact. British Journal of Sociology of Education, 37(1), 129-148.

Palfreyman, D., \& Tapper, T. (2014). Reshaping the university: The rise of the regulated market in higher education. Oxford: Oxford University Press.

Samuelson, P. (1954). The pure theory of public expenditure. Review of Economics and Statistics, 36(4), 387-389.

Sanchez-Fernandez, R., \& Iniesta-Bonillo, M. A. (2007). The concept of perceived value: A systematic review of research. Marketing Theory, 7(4), 427-451.

Schneider, C. G. (2008). Introduction. Liberal education and high-impact pedagogies. In D. Scott, G. Hughes, C. Evans, P. J. Burke, C. Walter, \& D. Watson (Eds.), Learning transitions in higher education. London: Palgrave.

Sellar, S. (2013). Equity, markets and the politics of aspiration in Australian higher education. Discourse: Studies in the Cultural Politics of Education, 34(2), 245-258.

Sen, A. (1985). Well-being, agency and freedom. Journal of Philosophy, LXXXII(4), 169-221.

Sen, A. (1999). Development as freedom. Oxford University Press: Oxford.

Skeggs, B. (2014). Values beyond value: Is anything beyond the logic of capital. British Journal of Sociology, $65(1), 1-20$.

Smith, C. (1992). Auctions: The social construction of value. Berkerly: University of California Press.

Temple, P. (2011). University branding: What can it do? Perspectives: Policy and Practice in Higher Education.

Tomlinson, M. (2017). Student perceptions of themselves as 'consumers' of higher education, British Journal of Sociology of Education, 38(4), 450-467.

Weber, M. (1948). From Max Weber: Essays in sociology, translated, edited and with an introduction by H.H. Gerth and C.W Mills. London: Routledge and Kegan Paul.

Weiler, H. (2005). Ambivalence and the politics of knowledge: The struggle for change in German universities. Higher Education, 49, 177-195.

Williams, J. (2012). Consuming higher education: Why learning can't be bought. London: Bloomsbury.

Zepke, N. (2014). Student engagement research in higher education: Questioning an academic orthodoxy. Teaching in Higher Education, 19(6), 697-708. 